\title{
Improving Tobacco Besuki Na-Oogst Competitiveness: Does Tobacco Still at a Crossroads?
}

\author{
Adhitya Wardhono \\ Faculty of Economics and Business, University of Jember, Indonesia \\ adhitya.wardhono@unej.ac.id \\ Josi Ali Arifandi \\ Faculty of Agriculture, University of Jember, Indonesia \\ aliarifandi@yahoo.com \\ Yulia Indrawati \\ Faculty of Economics and Business, University of Jember, Indonesia \\ yulia.feb@unej.ac.id \\ M. Abd. Nasir \\ Faculty of Economics and Business, University of Jember, Indonesia \\ abd.nasir@unej.ac.id \\ Ciplis Gema Qori'ah \\ Faculty of Economics and Business, University of Jember, Indonesia \\ ciplisqoriah@unej.ac.id
}

\begin{abstract}
Tobacco Besuki Na-Oogst (BesNO) is a fancy product and becomes a leading export-oriented commodity, especially as a raw material for making cigar. The embarrassment of Besuki Na-Oogst is a plant which has location specifics. Every tobacco-producing region has distinctive qualities. Tobacco Besuki NaOogst (BesNO) quality is measured using standards that are easily implemented by all tobacco Besuki NaOogst business actors. The research objective is to determine the competitiveness of tobacco Besuki $\mathrm{Na}$-Oogst as an export quality product. The analytical method used is descriptive analysis and SWOT. The research took place in Jember Regency Indonesia. The results show that tobacco Besuki $\mathrm{Na}$-Oogst's strategic potential is supported by supporting infrastructure capacity in testing tobacco quality, geographical potential and human resources in the face of competition and international policy. The strategy applied is to support aggressive growth policies through improving the quality of cultivation and capacity of standard infrastructure and the quality and quality of human resources in the face of international competitiveness.
\end{abstract}

Keywords: quality standards; competitiveness; export; tobacco Besuki Na-Oogst 


\section{INTRODUCTION}

Tobacco Besuki Na-Oogst (Bes-NO) is one type of tobacco that has quite high export potential as a raw material for making cigar. The quality of Bes-NO tobacco produced by Indonesia is one of the best tobaccos in the world, which is in the second rank after Brazil and almost 90 percent of international markets such as premium markets in Germany, Switzerland, the Netherlands, the United States and China favor to it (Utami et al, 2014). The development of cigar tobacco in Indonesia is concentrated in three regions, namely Deli (North Sumatra), Klaten, and Residency District (Djajadi, 2008). Jember Regency is the area with the largest planting area, which is about 80 percent of the total planting area. In general, Bes-NO tobacco planting areas managed by farmers reach 81.88 percent with $8,654.65$ ha while the rest is managed by State-Owned Enterprises (BUMN) and private companies (Basoenando, 2001; Soetriono, 2014). At present there are three types of Besuki NO tobacco cultivation patterns, namely traditional Besuki NO tobacco, early planting Besuki tobacco and shaded tobacco (TBN) (Arifien, 2013).

Compared to other plantation crops, tobacco Na-Oogst is a plant that has location specifics. Every tobacco-producing region has distinctive qualities and qualities. This is influenced by several aspects, namely environmental aspects and cultivation process carried out by farmers. Environmental conditions that affect the production and quality of tobacco include soil conditions, namely physical and chemical properties of soil, microclimates (temperature and humidity around the crop), texture, soil moisture, and rainfall. Another aspect is the elevation. Places with high elevation produce high quality tobacco, while those with low elevations produce low quality tobacco (Rochman \& Suwarso, 2000). Geographical differences in the regions of Jember regency have implications on tobacco management systems (Sholeh, 2000). 
Quality standardization is absolutely necessary to improve tobacco competitiveness in national and international markets. Quality requirements are the main barometer for buyers in determining selling prices and fluctuation of demand in the market. As a commodity, tobacco must meet the quality standards determined by the stakeholders of policy breakers so that it remains valid at certain limits. Quality standards can be defined as the degree or level of characteristics inherent in the product that meets the requirements or desires. Abdallah (1972) defines that the quality of tobacco is a combination of physical, chemical, organoleptic and economic properties that cause tobacco to be suitable or not for certain purposes. Tobacco quality can thus be measured using certain standards.

Determination of tobacco quality standards in Indonesia varies depending on where tobacco is planted. The standard contains several requirements that are used to measure level of quality of the tobacco. Technical quality standardization in Indonesia is contained in the Indonesian National Standard (SNI). At different levels, knowledge of SNI based quality of tobacco is still widely unknown by stakeholders at both upstream and downstream of tobacco agribusiness. Standardization is a regulation that entails technical requirements either directly or by referring to or by entering the contents of a standard or technical specification. Whereas standard is a written document containing rules, guidelines, characteristics of an item and/or service or a generally accepted process and method used repeatedly (National Standardization Agency, 2011). Standards are aimed at achieving optimum levels in certain contexts. They are set by referring to the international standards for the tobaccos can gain international recognition. They also aim to create a good and supportive climate in the trade.

In responding to the fundamental issues in the tobacco industry, importance of standards and quality is absolutely necessary to be able to compete globally. Therefore, to improve standard 
quality of tobacco Besuki Na-Oogst, this study aims to identify internal and external factors affecting improvement of standards and quality of tobacco Besuki Na-Oogst and formulate a policy strategy in increasing the competitiveness of Besuki Na-Oogst tobacco produced in Jember Regency.

\section{LITERATURE REVIEW}

Quality standards can be defined as the degree or level of characteristics inherent in the product that meets the requirements or desires. Physically, tobacco produced by a farmer is seemingly the same as that produced by the others. However, it can actually have different quality. Tobacco quality can be interpreted as a combination of physical, chemical, organoleptic and economic properties that cause tobacco to be suitable or not for particular purposes.

Understanding of tobacco quality can be based on several things, as follows:

1. Organoleptic properties are properties that appear without assistance of laboratory test and are generally subjective.

2. Instructive properties refer to physical and chemical ingredients contained in the leaves of tobaccos

3. Economic considerations relate to the development of global markets elements that also affect prices and ultimately are associated with quality requirements. They are

a. Residual Residues

b. Non-Tobacco Related Material (NTRM)

c. Tobacco Program (SRTP)

4. The quality characteristics based on Organoleptic which include:

a. Position of leaves on the stem (stalk position) 
b. Size and color of leaves (size, color)

c. Texture and structure of leaves

d. Damage (broken)

e. Disability of leaves

f. Soil

g. Non Tobacco Related Material (NTRM)

5. Properties on the basis of Instructivity:

a. Leaf physics which includes:

1) Spring power (filling power)

2) Elasticity

3) Water content (hydrocapacity)

4) Strength of leaf sheets (mechanical resistance)

b. Chemical leaves include:

1) Sugar content

2) Nicotine

3) Alkaline ingredients in leaves

4) Nitrogen

5) Protein Nitrogen

6) Pesticide residues

6. The economic considerations included in the element of quality are:

a. Pesticide residues.

b. The needs of the global market or local market compared to inventory.

c. Ability of exporters in implementing the Social Responsibility Program developed by BAT. 
d. Changes in market tastes. For example, originally tobacco painting wrapper (PW) were less favored by buyers but now cigarillos tobacco PW can be used, so that the price of tobacco PW can increase.

Business people use tobacco quality standards to measure quality of tobacco traded. Quality standards applied to measure tobacco quality are relatively the same even though some may apply different quality standards. Determination of tobacco quality standards in Indonesia varies depending on where tobacco are planted. The standard contains several requirements that are used to measure how high the quality of tobacco is.

\section{METHODOLOGY}

Type of data used in this study were primary and secondary data. The secondary data were gathered from the relevant agencies, including the Provincial and District/City Statistic Centers, Provincial and District Municipal Plantation Offices, UPT Testing and Certification of Quality of Jember Tobacco Institutions, Fiber Crop Research Institute (Balitas), Mining Associations, and other relevant agencies. Meanwhile the primary data was taken purposively using in-depth interview, questionnaires, and group discussion groups withtobacco farmers and entrepreneurs or exporters, academics, tobacco observers, UPT PSMB Tobacco Institutions, local governments and other relevant stakeholders. The strategic decision making process is related to determination of mission, goals, strategies and company policies.

The analytical method used in this study is SWOT (strength, weakness, opportunity, threat). In principle, the SWOT analysis results in a strong harmony between internal capabilities and external situations. SWOT analysis is an analysis that compares the external factors of opportunity and threats and the internal factors of strengths and weaknesses (Rangkuti, 2000: 
19). The SWOT analysis consists of stages of data collection, data analysis, and decision making. SWOT analysis has a weighting value based on a list of questions approved by the respondents. The SWOT matrix is a strategy matching tool based on the development of four types of strategies, namely SO Strategy (Strength-Opportunity), ST Strategy (Strength-Threat), WO Strategy (Weakness-Opportunity Strategy), and WT Strategy (Weakness-Threat Strategy). SO Strategy utilizes the internal strength of the tobacco agribusiness system to attract external benefits and opportunities. ST Strategy uses strengths to avoid or reduce the impact of external threats. WO Strategy improves the weaknesses of the Na-Oogst tobacco agribusiness system by taking advantage of external opportunities. WT Strategy is a tactic defensive aimed at reducing the weaknesses of the tobacco agribusiness system and avoiding external threats.

\section{RESULTS}

Tobacco Na-Oogst are qualified products that require special treatment ranging from the use of seeds, unexcessive fertilizers and pesticides, careful handling during and post-harvest and during transportation, and special standards of ripening rooms. Compared to other types of tobacco, NO tobacco requires greater costs. Besuki NO Tobacco is specifically planted in Jember Regency and a small part of Bondowoso Regency. The variety planted is H382 which has advantages for farmers, namely long and wide leaves, small and fine leaf or veins and good quality leaf. The need of fertilizer also varies by region in Jember Regency. The northern part of Jember area needs KS fertilizer around 90-120 kg N/ha, the central part of Jember requires $60 \mathrm{~kg} \mathrm{~N} / \mathrm{ha}$ for $\mathrm{KS}$ and urea fertilizer as a starter with $1,329 \mathrm{~kg} / \mathrm{ha}$ and quality deck-omblad 66.1 percent. Meanwhile the southern part of Jember requires a dose of $250 \mathrm{~kg} \mathrm{~N} / \mathrm{ha}$ from urea fertilizer. Geographical differences in the regions of Jember have implications on differences in tobacco management 
systems (Sholeh, 2000). The southern region of Jember requires cultivation technology in which $\mathrm{N}$ fertilization, irrigation and early age harvesting are suitable for the production dekblad and omblad with the result of kerosok reached $1,943 \mathrm{~kg} / \mathrm{ha}$ with quality deck-omblad 90.8 percent or 1,764 $\mathrm{kg} / \mathrm{ha}$. The southern region of Jember has water availability, temperature and air humidity and high light intensity.

Standards become one of the pillars of quality which is used as the main instrument to improve competitiveness of a country's commodities. Fulfillment of standard and quality requirements of export destination countries provides opportunities for gaining big export share according to the dynamics of economic development in the world. The free trade era forces producers to face increasingly fierce competition. This requires producers to increase efficiency and produce products that meet standards consistently in order to survive in the domestic market and international markets.

Standardization is a regulation that requires technical requirements either directly or by referring to or by entering the contents of a standard or technical specification. Whereas the standard is a written document containing rules, guidelines, characteristics of an item and/or service or a generally accepted process and method used repeatedly (National Standardization Agency, 2011). Standards are aimed at achieving optimum levels of order in certain contexts. The principles adopted in setting standards that as far as possible refer to international standards are intended to gain international recognition. The standard also aims to create a good and supportive climate in trade.

Determination of tobacco quality standards in Indonesia varies depending on where tobacco is planted. The standard contains several requirements that are used to measure the quality of tobacco. Technical quality standardization in Indonesia is contained in the Indonesian National 
Standard (SNI). At different levels, knowledge of SNI based quality of tobacco is still widely unknown by the stakeholders at upstream and downstream of tobacco agribusiness. Standardization is a regulation that requires technical requirements either directly or by referring to or by entering the contents of a standard or technical specification. Whereas the standard is a written document containing rules, guidelines, characteristics of an item and/or service or a generally accepted process and method used repeatedly (National Standardization Agency, 2011). Standards are aimed at achieving optimum levels in certain contexts. The principles adopted in setting standards that as far as possible refer to international standards are intended to gain international recognition. The standard also aims to create a good and supportive climate in the trade.

At this time definition of quality globally not only focuses on the quality of the final product but also on the integrated quality assurance system where the process of handling and processing produces good quality products. In its implementation, supervision of standards and quality is often still low. Some business actors still consider that quality certificates are not needed because they are not requested by buyers. Inadequate infrastructure of testing institution and high cost of managing certification are the main problem in implementing standards and quality. Therefore, the application of standards and quality is very strategically effort to increase competitiveness in exporting. The international quality standard which is currently the main requirement for exports, among others, is that tobacco must be free from pesticide residues and Non Tobacco Related Materials (NTRM) and this requirement has not yet been fulfilled widely because generally farmers are still using chemical pesticides for pest control. Nevertheless, many countries have required pesticide residual thresholds.

Identification potentials and problems becomes highly important for mapping strategic position of Indonesian tobacco quality standards in the international market so that competitiveness 
of the tobacco exported can be increased. Mapping potential or identifying strategic position in applying standards and quality of tobaccos include 27 factors consisting of 19 internal factors and eight external factors. Internal factors that are relate to potential in applying Indonesian tobacco standards and quality to increase export competitiveness are good relations between companies and importers in the destined countries, availability of export certification, existence of corporate culture that maintains product quality.

The other internal factors are existence of production facilities that are in accordance to international standards, and of good relations with suppliers and farmers. In addition to those, there are laboratories for testing and fostering tobacco quality, good quality of human resources, and superiority of the commodities in terms of many varieties and peculiarities according to specific locality. While internal weaknesses include limited staff of testing and laboratory equipment, seasonal availability of commodities, limited export infrastructure in ports, limited access to information on standardization, low quality of tobacco leaves, and high production costs. 
Table 1. SWOT Diagram of Strategic Position of Tobacco Standards and Quality

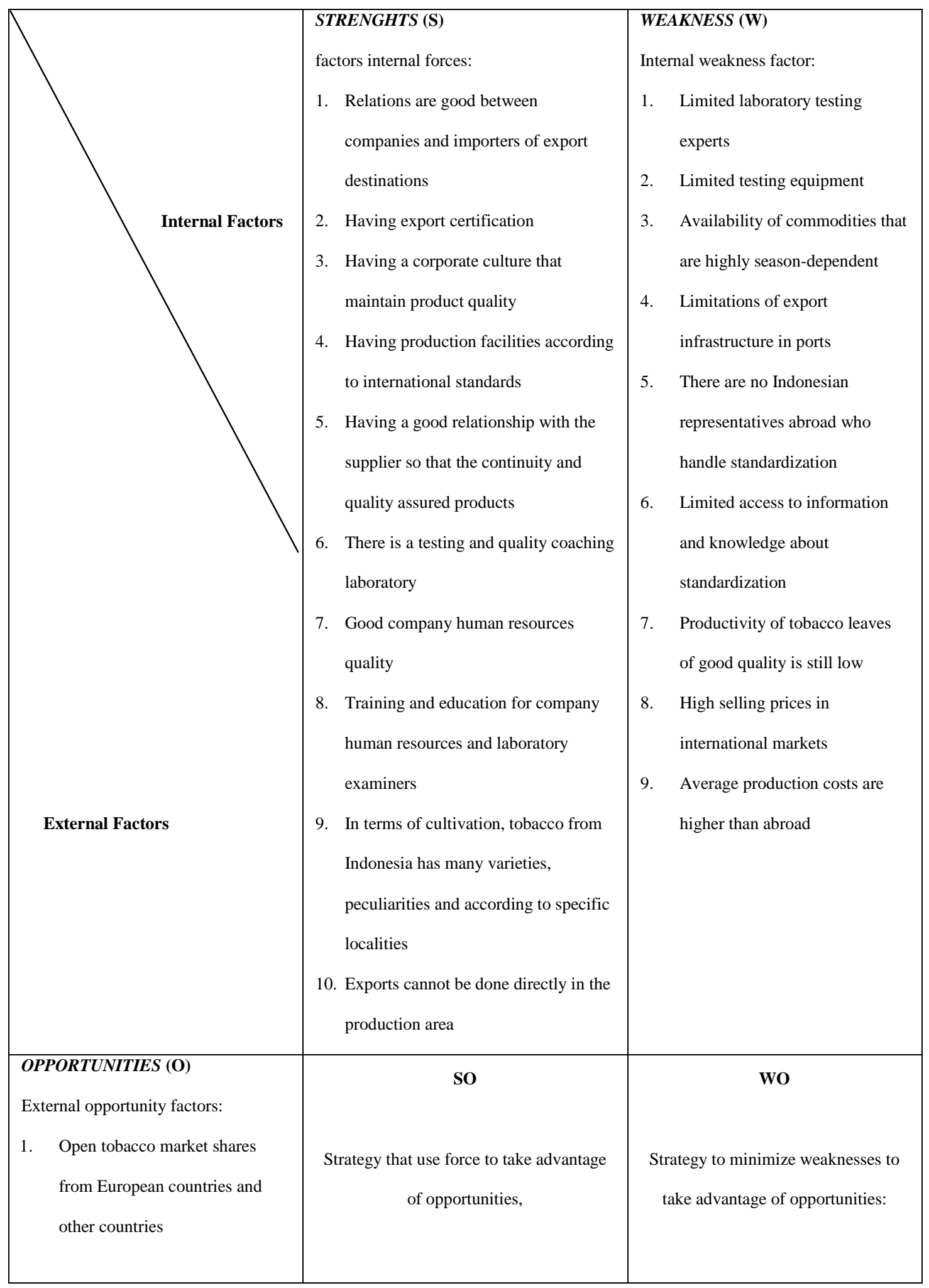




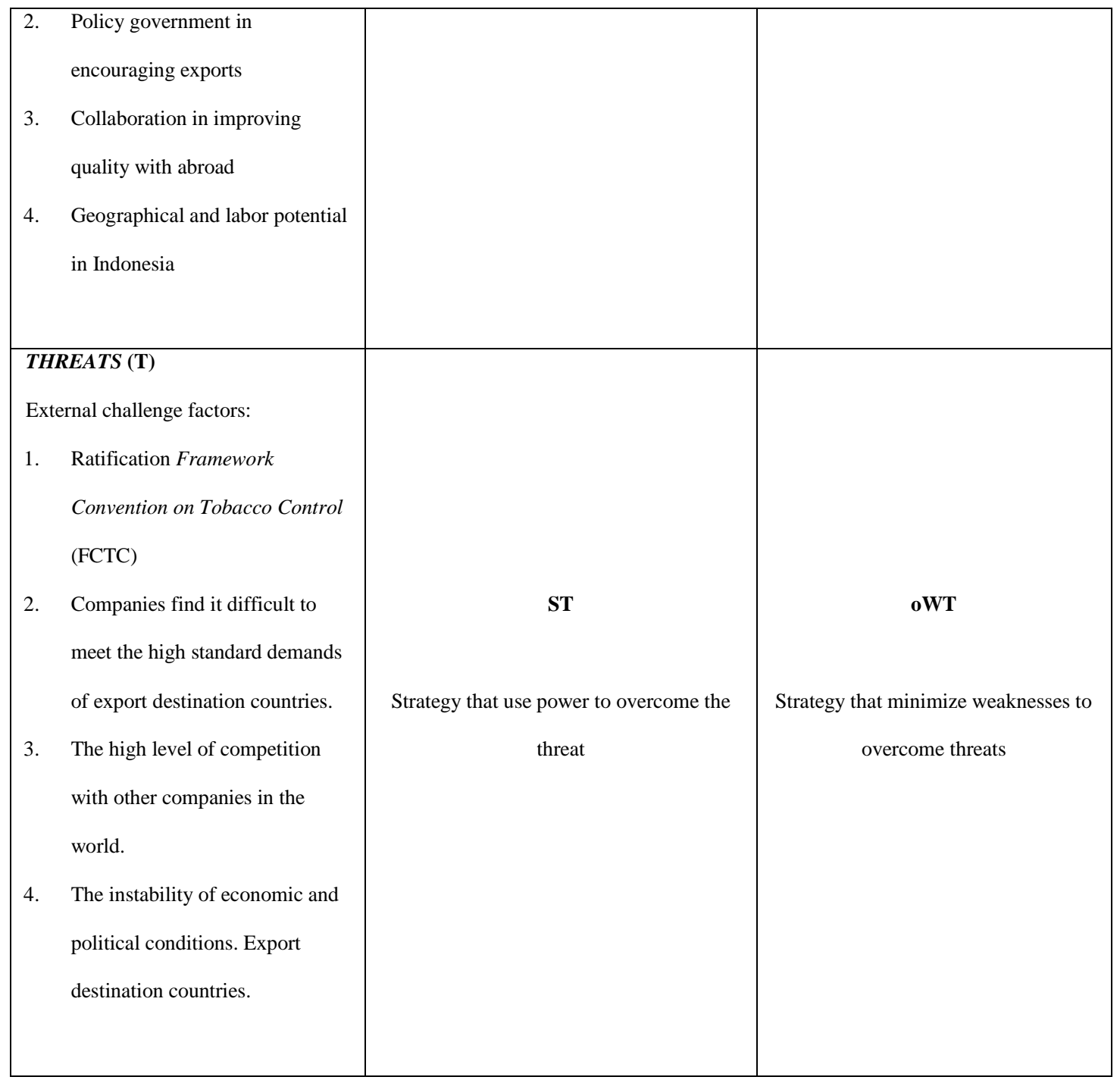

Source: Primary Data, processed, 2018

Opportunities, the external factor, include open international market for tobacco, government policies in promoting exports, cooperation in improving the quality and geographical and human resources potentials. Whereas the external constraints are existence of international policy ratification of the Framework Convention on Tobacco Control, difficulty of the companies to meet the high standard demanded by the export destination countries, high level of competition with other companies in the world and the instability of economic and political conditions of export destination countries. 
Based on the identification of the internal potential of the application of Indonesian tobacco standards and quality to increase export competitiveness, it reveals that the strength factor is still greater than the weakness. This condition indicates that the internal potential is good in terms of the capacity of supporting infrastructure in testing tobacco quality and geographical potential and human resources in minimizing the weakness of human resource capacity and productivity of tobacco cultivation. Therefore, there is a need for intensive efforts to increase supporting infrastructure capacity and production quality and human resource capacity in facing international markets.

Table 2. Results of Mapping Internal Factors in the Application of Tobacco Standards and

\section{Quality Besuki Na-Oogst}

\begin{tabular}{|c|c|c|c|c|}
\hline & onents of Internal Factors (Strength) & Weight & Score & Value \\
\hline 1. & $\begin{array}{l}\text { relations between companies and importers of export } \\
\text { destination countries }\end{array}$ & 0.06 & 4 & 0.21 \\
\hline 2. & Having export certification & 0.06 & 4 & 0.24 \\
\hline 3. & Has a corporate culture that maintains product quality & 0.06 & 4 & 0.24 \\
\hline 4. & $\begin{array}{l}\text { Has production facilities according to international } \\
\text { standards }\end{array}$ & 0.06 & 4 & 0.24 \\
\hline 5. & $\begin{array}{l}\text { Has good relations with suppliers so continuity and } \\
\text { product quality guaranteed }\end{array}$ & 0.06 & 4 & 0.24 \\
\hline 6. & $\begin{array}{l}\text { There is a laboratory for testing and guiding tobacco } \\
\text { quality }\end{array}$ & 0.06 & 4 & 0.24 \\
\hline 7. & quality of the company's human resources is good & 0.06 & 4 & 0.24 \\
\hline 8. & $\begin{array}{l}\text { There is training and education for the company's } \\
\text { human resources and laboratory testers }\end{array}$ & 0.05 & 3 & 0.16 \\
\hline
\end{tabular}




\begin{tabular}{|c|c|c|c|c|}
\hline 9. & $\begin{array}{l}\text { In terms of cultivation, tobacco from Indonesia has } \\
\text { many varieties, peculiarities and according to locality } \\
\text { specific }\end{array}$ & 0.05 & 3 & 0.15 \\
\hline 10. & Exports cannot be done directly in the production area & 0.04 & 2 & 0.08 \\
\hline \multicolumn{2}{|c|}{ Total } & 0.55 & & 2.04 \\
\hline \multicolumn{2}{|c|}{ Weaknesses } & & & \\
\hline 1. & Limited expertise $\mathrm{p}$ laboratory testing & 0.05 & 4 & 0.20 \\
\hline 2. & Testing equipment is limited & 0.05 & 3 & 0.17 \\
\hline 3. & Availability of highly dependent seasonal commodities & 0.06 & 4 & 0.21 \\
\hline 4. & Infrastructure export limitations in ports & 0.04 & 3 & 0.12 \\
\hline 5. & $\begin{array}{l}\text { There is no Indonesian representative abroad who } \\
\text { handles standardization }\end{array}$ & 0.04 & 3 & 0.12 \\
\hline 6. & $\begin{array}{l}\text { Limited access to information and knowledge } \\
\text { regarding standardization }\end{array}$ & 0.04 & 3 & 0.12 \\
\hline 7. & Productivity of good quality tobacco leaves is still low & 0.06 & 4 & 0,23 \\
\hline 8. & High selling prices on the international market & 0.05 & 3 & 0.16 \\
\hline 9. & Average production costs are higher than foreign ones & 0.05 & 4 & 0.20 \\
\hline \multicolumn{2}{|c|}{ Total } & 0.45 & & 1.53 \\
\hline \multicolumn{4}{|c|}{ Difference Strengths and Weaknesses } & 0.51 \\
\hline
\end{tabular}

Sources: Primary Data, processed, 2018

While based on the identification of potential in the application of tobacco standards and quality in dealing with international markets, the external factors show that the opportunities are greater than the threats. This condition shows that quality of Indonesian tobacco is quite capable to capture external opportunities against to all possible external threats. This condition indicates that external potential is good in terms of the capacity of supporting infrastructure in testing tobacco 
quality and geographical potential and human resources in the face of competition and the existence of international policies. Therefore, intensive efforts in strengthening the standards and quality institutions and increasing production capacity and human resources in the face of competition and international policy are needed.

Table 3. Mapping of External Factors in the Application of Standards and Quality Tobacco

\section{Besuki Na-Oogst}

\begin{tabular}{|c|c|c|c|c|}
\hline & Components External Factors & Weight & Score & Value \\
\hline & ortunities & & & \\
\hline 1. & $\begin{array}{l}\text { The opening of the tobacco market share of European } \\
\text { countries and other countries }\end{array}$ & 0.13 & 4 & $0: 44$ \\
\hline 2. & The government policy in encouraging export & 0,14 & 4 & 0.51 \\
\hline 3. & Cooperation in improving quality with foreign countries & 0.13 & 4 & 0.44 \\
\hline 4. & Geographical and labor potential in Indonesia & 0.13 & 4 & 0.47 \\
\hline & Total & 0.52 & & 1.86 \\
\hline & ats / Challenges & & & \\
\hline 1. & $\begin{array}{l}\text { Ratification of the Framework Convention on Tobacco } \\
\text { Control }\end{array}$ & 0.12 & 3 & 0.41 \\
\hline 2. & $\begin{array}{l}\text { Companies find it difficult to meet high standard } \\
\text { demands from export destination countries }\end{array}$ & 0.13 & 4 & 0.44 \\
\hline 3. & $\begin{array}{l}\text { High level of competition with other companies in the } \\
\text { world }\end{array}$ & 0.13 & 4 & 0.47 \\
\hline 4. & $\begin{array}{l}\text { Instability in economic and political conditions Export } \\
\text { destination countries }\end{array}$ & 0.10 & 3 & 0.30 \\
\hline & Total & 0.48 & & 1.62 \\
\hline & Difference in Opportunities and Challenges & reats & & 0.24 \\
\hline
\end{tabular}

Source: Primary Data, processed, 2018 
Based on internal and external conditions, a comprehensive and integrative strategy is needed, namely (1) a strategy to increase supporting infrastructure capacity in increasing competitiveness; (2) strategies to improve production quality and human resource capacity in the face of international markets; (3) strategies to strengthen institutional standards and quality in the face of competition and international policy; (4) strategies to increase production capacity and human resources in the face of competition and international policy.

Based on mapping in the SWOT matrix, the results show that the strategic position in the application of Indonesian tobacco standards and quality is in quadrant I, which is indicated by the value of internal factors of 0.51 and external factors of 0.24 . Quadrant I is a very profitable position in which the tobacco commodity has the opportunity and strength so that it can take advantages of the existing opportunities optimally. The strategy adopted is to support aggressive growth policies by improving the quality of cultivation and capacity of standard infrastructure and quality and human resources in the face of international competitiveness.

Several alternative strategies in applying Indonesian tobacco standards and quality are as follows:

1. Increase the application of quality management and maintaining the quality of the products produced and include it in the company's technical capabilities to maintain the continuity of tobacco exports. On the other hand, concern for standardization is also important so that exported products are acceptable according to the technical requirements of the export destination countries. One effort is to intensively provide standardization training and other relevant trainings such as training for test laboratory personnels aas well as provide infrastructure for testing standards and quality of tobacco in the country. 


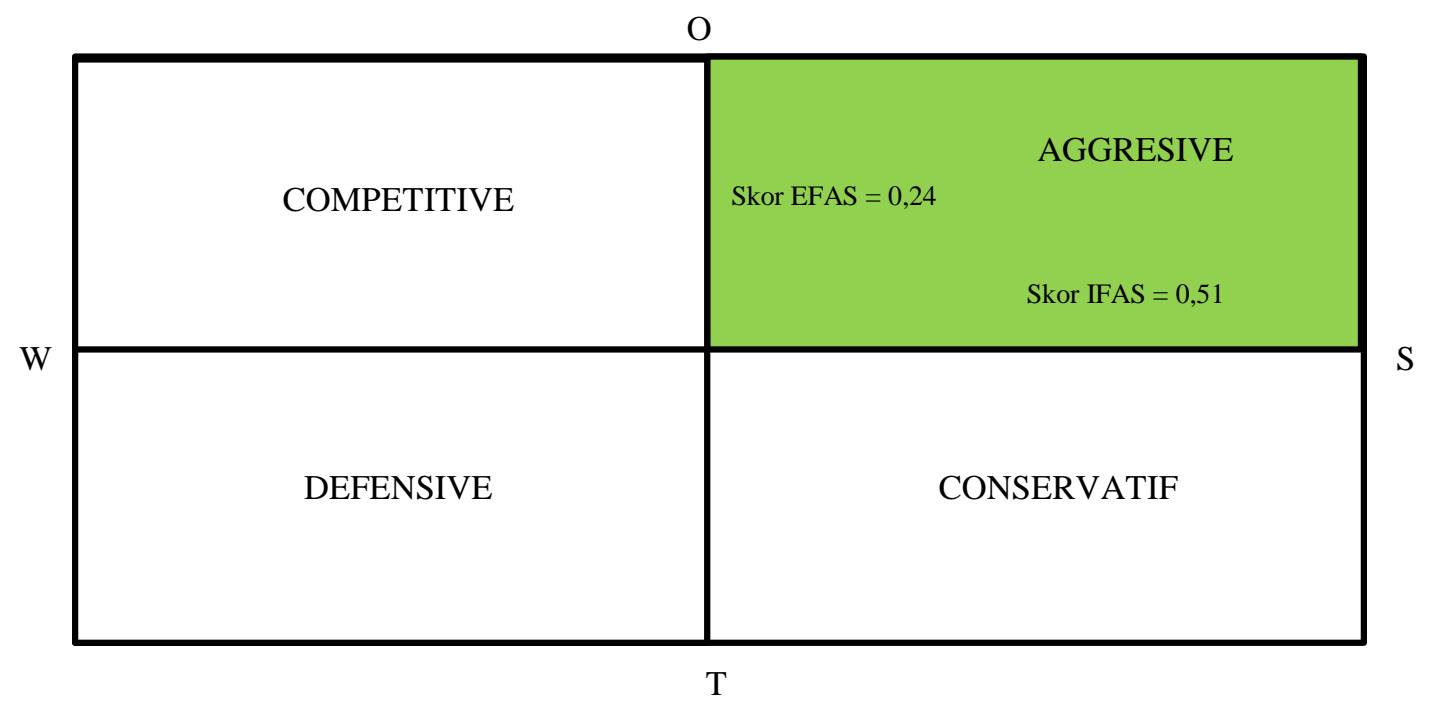

Source: Primary Data, processed, 2018

Figure 1. Strategic Position of Besuki Na-Oogst Tobacco Commodities in the Implementation of Standards and Quality

2. Increase the availability of infrastructure to support standards and quality in a more complete manner and easily accessible in the country. The supporting infrastructure includes the procurement of test equipments. Incentives for the procurement of laboratories and other quality facilities encourage improvement of the quality and standards of tobacco exported for improving its competitiveness.

\section{CONCLUSION AND POLICY IMPLICATIONS}

\section{Conclusion}

Tobacco Besuki Na-Oogst is an export-oriented quality product that must pay attention to standards and quality in order to be competitive in the international market. Mapping Indonesia's strategic competitiveness position results in quadrant I with an aggressive strategy in which the internal factors adhered in Indonesian tobacco are able to capture opportunities and minimize the 
threats. The strategy to increase the competitiveness of Indonesian tobacco in accordance to this strategic position is to improve the quality of cultivation and capacity of standard infrastructure and quality and human resources in the face of international competitiveness.

\section{Policy Implications}

1. Improve the quality of cultivation from upstream to downstream so that it is competitive by increasing location-specific productivity and requirements for pesticide residue standards and strengthening farming institutions.

2. Strengthen cooperation and negotiations in international tobacco-related agreements by strengthening bargaining positions.

3. Implement tobacco quality standards for the stakeholders in more easily applicable way.

4. Strengthen institutional role of the testing infrastructures as follows:

a. Increase capacity of human resources and number, scope and competence of infrastructure in laboratories, inspection bodies and certification.

b. Regarding to international certification, it is expected that domestic certification institutions can make Memorandum of Understanding with foreign certification bodies to certify products needed by exporters. This is to reduce costs and simplify the procedures. In the long run, competitiveness in terms of standards and quality is higher. It is necessary to establish a national Quality Infrastructure based on five pillars, namely standardization, metrology, testing, accreditation and certification. 


\section{REFERENCES}

Arifien, M. S. (2013). Tembakau di Persimpangan Jalan. Dinas Perkebunan Provinsi Jawa Timur.

Badan Standardisasi Nasional. (2012). Informasi Standar Nasional Indonesia Produk Unggulan untuk Mendukung MP3EI. Jakarta: Badan Standardisasi Nasional.

Badan Standardisasi Nasional. (2011). SNI Penguat Daya Saing Bangsa. Jakarta: Badan Standardisasi Nasional.

Balai Pengujian Sertifikasi Mutu Barang Dan Lembaga Tembakau (BPSMBLT) dengan Komisi Urusan Tembakau Jember (KUTJ). (2008). Good Manufacturing Practices (GMP) Tembakau Besuki Na-Oogst (disampaikan pada Sosialisasi Penyusunan dan Penerapan Sistem Good Manufacturing Practices (GMP) Tembakau Na-Oogst dan Voor-Oogst). Jember: BPSMB-LT dan KUTJ.

Basoenando. (2001). Pemasaran Tembakau Besuki NO, Produksi Petani di Kabupaten Jember, Faktor-faktor yang Berpengaruh dan Strategi Pengembangannya. Unpublised master thesis. University of Jember.

Beaglehole, et al. (2015). A tobacco-free world: A call to action to phase out the sale of tobacco products by 2040. Lancet. 385, 1011-1018. doi:10.1016/S0140-6736(15)60133-7

Djajadi. (2008). Tembakau Cerutu Besuki-NO: Pengembangan Areal dan Permasalahannya di Jember Selatan. Perspektif, 7 (1), 12-19.

Kementerian Perdagangan Republik Indonesia. (2012). Laporan Akhir Kajian Kebijakan Mutu Dan Standar Produk Ekspor Tertentu Dalam Meningkatkan Daya Saing. Jakarta: Badan Pengkajian dan Pengembangan Kebijakan Perdagangan Pusat Kebijakan Perdagangan Luar Negeri Jakarta. 
Kementerian Pertanian. (2013). Statistik Perkebunan Indonesia 2011-2013. Jakarta: Kementerian Pertanian.

Muchfirodin, M., Guritno, A.D., dan Yuliando, H. (2015). Supply Chain Risk Management on Tobacco Commodity in Temanggung, Central Java (Case Study at Farmers and Middlemen Level). Agric. Agric. Sci. Procedia. 3, 235-240. doi:10.1016/j.aaspro.2015.01.046.

Myring, P. (2000). Qualitative content analysis. Forum Qualitative Social Research. 1(2), 1-10.

Negri, M., \& Porto, G.G. (2016). Burley tobacco clubs in Malawi: Nonmarket institutions for exports. Int. Econ. 146, 85-107. doi:10.1016/j.inteco.2015.11.004

North, G. (1992). The Coase Theorem: A Study in Economic Epistemology. Institute of Christian Economics. Texas.

Nur, Y. H. \& Devi, A. (2013). Daya Saing Tembakau Virginia Lokal di Pasar Dalam Negeri. Buletin Ilmiah Litbang Perdagangan. 7 (1), July.

Onder. (2010). The Economics of Tobacco Use \& Tobacco Control in the Developing World. Niger. J. Physiol. Sci. 25, 81-86.

Padmo, S. \& Djatmiko, E. (1991). Tembakau Kajian Sosial Ekonomi. Yogyakarta: Aditya Media Yogyakarta.

Peraturan Daerah Kabupaten Jember Nomor 7 Tahun 2003 tentang Pengusahaan Tembakau.

Peraturan Menteri Pertanian Nomor 56/Permentan/OT.140/9/2012 tentang Pedoman Penanganan Pascapanen Tembakau.

Peraturan Pemerintah Nomor 102 Tahun 2000 tentang Standardisasi Nasional Indonesia.

Quisenberry, A.J., Koffarnus, M.N., Epstein, L.H, \& Bickel, W.K. (2017). The Experimental Tobacco Marketplace II: Substitutability and sex effects in dual electronic cigarette and 
conventional cigarette users. Drug Alcohol Depend. 178, 551-555. doi:10.1016/j.drugalcdep.2017.06.004

Rangkuti, F. (1999). Analisis SWOT Teknik Membedah Kasus Bisnis. Jakarta: PT Gramedia Pustaka Utama.

Rochman, F. \& Suwarso. (2000). Kultivar Lokal Tembakau Temanggung dan Usaha Perbaikannya dalam Tembakau Temanggung. Dalam Monograf Balittas (5, 71-86). Balai Penelitian Tembakau dan Tanaman Serat Malang.

Sholeh, M., A. R, \& Machfudz. (2000). Pengaruh kombinasi pupuk KS, ZA, dan Urea, serta dosis N terhadap mutu tembakau cerutu besuki NO di Jember. J. Penel. Tan. Industri. 6(3), 8087.

Sihem, E. (2017). Economic and socio-cultural determinants of agricultural insurance demand across countries. J. Saudi Soc. Agric. Sci. doi:10.1016/j.jssas.2017.04.004

Soetriono et al. (2014). Agribisnis Tembakau Besuki Na-Oogst: Tinjauan Ekonomi Pertanian Surya Pena Gemilang.

Tso, T.C. (1972). Physiology and biochemistry of tobacco plants 140 p. Stroudsburg, Pa: Dowden, Hutchinson and Ross Inc.

Utami, S. W., A. Daryanto, \& H. Rujito. (2014). Strategi Peningkatan Daya Saing Tembakau Besuki Na-Ooogst Berbasis Perbaikan Kinerja Mutu. Jurnal Manajemen \& Agribisnis. 11(2), July. 